\title{
The Impact of Service Quality Dimensions on Patient Satisfaction and Loyalty Using The Modified Servqual Scala At Dr. Abdoer Rahem Situbondo Hospital
}

\author{
Budiharto \\ Planning Section Chief of Dr. Abdoer Rahem Hospital, Situbondo \\ budic.harto@gmail.com
}

\begin{abstract}
The focus of this study is on the influence of the quality of hospital inpatient health services according to the modified servqual scala dimension on patient satisfaction and loyalty. Satisfaction plays a role as a mediator of service quality in creating patient loyalty. With a sample of 400 inpatients participating in this study through a questionnaire survey with 15 questionnaires not returned / not answered completely. Samples were taken randomly from patients who received inpatient services with a purposive sampling method. Data were analyzed by path analysis using the SPSS program. The results of the study indicate that the quality of health services concerning the dimensions of trustworthness, communication, infrastructural quality, emphaty and responsiveness have a positive and significant effect on patient satisfaction in the inpatient installation of RSUD dr. Abdoer Rahem Situbondo with the dimension of responsiveness that has the greatest impact on satisfaction; The quality of health services regarding the dimensions of trustworthness, communication, emphaty, reliability and responsiveness through patient satisfaction have a positive and significant effect on patient loyalty in the inpatient installation of RSUD dr. Abdoer Rahem Situbondo but the personnel, healthscape, infrastructural quality does not have a significant effect. Patient satisfaction at the inpatient facility has a positive and significant effect on patient loyalty.
\end{abstract}

Keywords : Hospital, Servqual, Satisfaction, Loyalty

\section{INTRODUCTION}

Hospitals as public organizations in the field of health services, must have a competitive advantage, especially in the era of globalization which faces many challenges in carrying out basic tasks and functions such as increasing expectations of service quality, limited resources, potential conflicts, demands for technological development, many strict guidelines and rules. For this reason, hospitals continue to pay attention to the dynamics of customer needs, desires and preferences and try to fulfill them in ways that are more effective and efficient compared to their competitors.

Meanwhile, service quality has always been a major factor in measuring performance. Service quality is an overall evaluation of the customer on the service process provided by the service provider. In the health industry, the quality of results is the main determinant in assessing the perception of the quality of patient services. According to Zeithaml (1988), quality is perceived subjectively by consumers about the overall superiority of the product in referring to competitive offers. Likewise, perceived service quality is generally defined as consumers' assessments of, or impressions about, the overall superiority or superiority of an entity. A number of factors can influence 
consumer quality assessments, including personal product experience, special needs, and consumption. High perceived quality will foster trust and motivate consumers to re-choose those services over competing products.

From a variety of service quality measurement models, the Servqual model seems to be adequate in hospitals, but non-Servqual developments need to be considered, therefore researchers wish to measure hospital service quality by adopting non-servqual quality dimension indicators such as the PAI, YP \& Chary (2016) models., Padma et al. (2009), Swain \& kar (2017) into the Servqual model (Parasuraman, Berry, Zeithmal, 1988).

In Situbondo, currently has 5 hospitals, namely $2 \mathrm{C}$ class hospitals and $3 \mathrm{D}$ class hospitals. Each competes according to its class. RSUD dr. Abdoer Rahem Situbondo is a hospital owned by the Government of Situbondo Regency which has class C capacity of 265 beds and has adequate human resources, especially the availability of 27 specialist doctors spread across various types of services. It is this type of service and HR that becomes the basis for competing to provide the best health services.

Based on the medical record report, the situation of the patient's visit at RSUD dr. Abdoer Rahem Situbondo from 2016 to 2018 experienced a downward trend of $10.4 \%$, in 2016 there were 107,587 patients, while in 2018 there were 96,675 people. On the other hand the level of satisfaction at the hospital tends to not be on target:

Table 1.l Public Satisfaction Index for health services in RSUD dr. Abdoer Rahem Situbondo in 2018

\begin{tabular}{|c|c|c|c|}
\hline Number & Work Unit & Target & Realization \\
\hline 1. & Emergency Departments & $\geq 76,61$ & 64,9 \\
\hline 2. & Polyclinic & $\geq 76,61$ & 64,6 \\
\hline 3. & Inpatient & $\geq 76,61$ & 55,5 \\
\hline \multicolumn{2}{|r|}{ (RSAR IKM Report for 2018) } \\
\hline
\end{tabular}

(RSAR IKM Report for 2018)

Based on the above, it appears that there is a gap between the target index of satisfaction with realization, and the declining trend in patient visits could this be due to the declining quality of health services in hospitals which has an effect on satisfaction and can subsequently affect patient loyalty. Departing from the research gap and theory the study this takes the focus on "The Impact of Service Quality Dimensions on Patient Satisfaction and loyalty using the modified servqual scala at $\mathrm{dr}$. Abdoer Rahem Situbondo hospital".

In this research, the author want to see: First, is there any influence on the quality of inpatient health services on patient satisfaction. Second, is there an influence on the quality of inpatient services on patient loyalty mediated by satisfaction, and third, is there an influence on patient satisfaction on inpatient loyalty.

The objectives of this research are: First, to analyze the effect of the quality of inpatient health services on patient satisfaction by using the modified servqual scala . Second, to analyze the effect of inpatient service quality on patient loyalty mediated by 
satisfaction using the modified servqual, and third, to analyze the effect of patient satisfaction on inpatient loyalty.

According to Mardalis (2002: 48), a hypothesis is a temporary answer or conclusion drawn to answer the problem raised in the study. Trelease (1960), the hypothesis is also a temporary statement of an observable fact. According to Kerlinger (1973) the hypothesis is a conjectural statement of the relationship between two or more variables. From this description, it can be obtained a hypothesis (provisional estimates) based on previous opinions and studies, as follows:

1. Hl: All dimensions of the modified SERVQUAL in the form of trustworthness (X1), Personnel (X2), Communication (X3), Healthscape (X4), infrastructural quality (X5), Emphaty (X6), Reliability (X7) and Responsiveness (X8) have a significant effect on inpatient satisfaction (Z) at RSUD dr. Abdoer Rahem Situbondo.

2. H2: All dimensions of the modified SERVQUAL in the form of Trustworthness (X1), Personnel (X2), Communication (X3), Healthscape (X4), infrastructural quality (X5), Emphaty (X6), Reliability (X7) and Responsiveness (X8) mediated by Satisfaction have a significant effect on the loyalty of inpatients (Y) in RSUD dr. Abdoer Rahem Situbondo.

3. H3: Patient satisfaction ( $Z$ ) has a significant effect on Inpatient (Y) patient loyalty at RSUD dr. Abdoer Rahem Situbondo.

\section{METHODOLOGY}

The analysis technique that can be used to determine the relationship between these variables is path analysis with SPSS application. Eight dimensions of service quality include: Trustworthness, Personnel, Communication, Healthscape, infrastructural quality, Emphaty, Reliability and Responsiveness act as exogenous variables, while satisfaction as an endogenous variable and patient loyalty as a second endogenous variable.

The population in this study were all patients who were inpatients at RSUD dr. Abdoer Rahem Situbondo Regency. Therefore the total population in this study is not known with certainty. While the sample in this study was 400 inpatients from September to October 2019, with the patient undergoing treatment for at least 3 days, and in a conscious condition. A total of 385 (96.25\%) patients participated in this study.

In this research the five-point Likert scale is used to measure three categories of structures (quality of hospital services, patient satisfaction and patient loyalty). Researchers use eight dimensions of hospital service quality (Trustworthness, Personnel, Communication, Healthscape, infrastructural quality, Emphaty, Reliability and Responsiveness), as proposed by Parasuraman, Zeithaml, Berry (1988), Babakus and Mangold (1992), Bakar (2008), by adopting a model from Pai and Chary, (2016), Karr and Swain (2018) so that the servqual contain 22 indicators and servqual modified instrument increased from 22 to 39 indicators. 


\section{RESULTS AND DISCUSSION}

The classic assumption test results in the path analysis include the Kolmogorov Smirnov normality test which has a normal distribution with the Asymp count results. Sig. (2-tailed) Unstandardized Residual is $0.131>$ of 0.05 so the regression is feasible to use. the results of multicollinearity test values of VIF (variance inflation factor) $<10$ shows that the regression model is free from multicollinearity symptoms.

\section{A. Model and Equation Structure of Path Analysis.}

\section{Substructure Equation 1}

Substructure equation 1 illustrates the effect of service quality (X1, X2, X3, X4, X5, $\mathrm{X} 6, \mathrm{X} 7, \mathrm{X} 8)$ on satisfaction $(Z)$. The following path coefficient values are obtained:

Table 3.1. Path Coefficient For substructure Equation 1

\begin{tabular}{lccccccc}
\hline \multicolumn{1}{c}{ Relationship } & to & $\begin{array}{c}\text { Koef. } \\
\text { beta }\end{array}$ & $\begin{array}{c}T \\
\text { count } \\
\text { it }\end{array}$ & Sig. & $\begin{array}{c}F_{\text {count }} \\
\text { it }\end{array}$ & Sig. & $R^{2}$ \\
\hline$X_{1}$ (Trustworthness) & satisfaction & 0,127 & 2,686 & 0,008 & & & \\
$X_{2}$ (personnel) & $(Z)$ & $-0,11$ & $-0,177$ & 0,860 & & & \\
$X_{3}$ (communication) & & 0,138 & 2.464 & 0,014 & 53,231 & 0,000 & 0,531 \\
$X_{4}$ (healthscape) & 0,073 & 1,331 & 0,184 & & & \\
$X_{5}$ (infrastructural & & & 2,210 & 0,028 & & & \\
$\quad$ quality) & 0,115 & 3,579 & 0,000 & & & \\
$X_{6}$ (emphaty) & 0,177 & 3,062 & 0,106 & & & \\
$X_{7}$ (reliability) & 0,087 & 1,622 & & & & \\
$X_{8}$ (responsiveness) & 0,226 & 4,333 & 0,000 & & & \\
\hline
\end{tabular}

(Research Results)

Based on Table 3 it can be seen that the value of Fcount $=53,231>$ Ftable $=2.237$. This means that the variable Trustworthness, Personnel, Communication, Healthscape, infrastructural quality, Emphaty, Reliability and Responsiveness simultaneously affect the patient satisfaction variable by $53.1 \%$, the remaining $46.9 \%$ or residual value e = 0.684 caused by other factors not examined. Furthermore, partial testing is done by comparing $t$ arithmetic with $t$ table $=1.966$. In Table 3 it can be seen that the $t$ count on the personnel variable (X2), healthscape (X4) and the reliability variable (X7) is less than the table. This means that the path coefficient of the personnel variable (X2), healthscape (X4) and the reliability variable (X7) does not significantly influence satisfaction. So that the obtained sub-structure equation 1 with Servqual modified :

$Z=0,127 X_{1} Z+0,138 X_{3} Z+0,115 X_{5} Z+0,177 X_{6} Z+0,226 X_{8} Z+0,684 e_{1}$ 
2. Substructure Equation 2

Substructure equation 2 illustrates the effect of service quality (X1, X2, X3, X4, $\mathrm{X} 5, \mathrm{X} 6, \mathrm{X} 7, \mathrm{X} 8)$ and satisfaction (Z) on Loyalty (Y). The following path coefficient values are obtained:

Table 3.2. Path Coefficient For Sub-Structure Equation 2.

\begin{tabular}{|c|c|c|c|c|c|c|c|}
\hline \multicolumn{2}{|c|}{ Relationship } & \multirow{2}{*}{$\begin{array}{l}\text { Koef. } \\
\text { beta }\end{array}$} & \multirow{2}{*}{$\begin{array}{c}T \\
\text { count } \\
\text { it }\end{array}$} & \multirow[b]{2}{*}{ Sig. } & \multirow[b]{2}{*}{$\begin{array}{l}\mathrm{F}_{\text {count }} \\
\text { it }\end{array}$} & \multirow[b]{2}{*}{ Sig. } & \multirow[b]{2}{*}{$\mathrm{R}^{2}$} \\
\hline From & To & & & & & & \\
\hline $\mathrm{X}_{\mathrm{l}}$ (Trustworthness) & satisfaction & 0.086 & 2.099 & 0.037 & & & \\
\hline $\mathrm{X}_{2}$ (personnel) & $(Z)$ & 0.028 & 0.548 & 0.584 & & & \\
\hline $\mathrm{X}_{3}($ communication $)$ & & 0.079 & 1.629 & 0.104 & 79,818 & 0,000 & 0,657 \\
\hline $\mathrm{X}_{4}$ (healthscape) & & 0.043 & 0.908 & 0.365 & & & \\
\hline $\begin{array}{l}X_{5} \text { (infrastructural } \\
\text { quality) }\end{array}$ & & -0.033 & -0.727 & 0.467 & & & \\
\hline $\mathrm{X}_{6}($ emphaty $)$ & & 0.080 & 1.855 & 0.064 & & & \\
\hline $\mathrm{X}_{7}($ reliability $)$ & & 0.099 & 2.160 & 0.031 & & & \\
\hline $\mathrm{X}_{8}$ (responsiveness) & & 0.088 & 1.934 & 0.054 & & & \\
\hline Z (satisfaction) & & 0,501 & 11,335 & 0,000 & & & \\
\hline
\end{tabular}

(Research Results)

Based on Table 4 it can be seen that the calculated $\mathrm{F}$ value $=79,818>\mathrm{F}$ table $=$ 2.237. This means that the variable Trustworthness, Personnel, Communication, Healthscape, infrastructural quality, Emphaty, Reliability and Responsiveness simultaneously affect the patient loyalty variable by $65.7 \%$ while the remaining $34.3 \%$ or residual value $\mathrm{e}=0.574$ is caused by other factors not examined. Furthermore, partial testing is done by comparing $t$ arithmetic with $t$ table $=1.966$. In Table 4 it can be seen that $t$ arithmetic on personnel variables (X2), communication (X3), healthscpae (X4), infrastructural quality(X5), emphaty (X6), responsiveness (X8) is less than t table. This means that the personnel path coefficient (X2), communication (X3), healthscpae (X4), infrastructural quality(X5), emphaty (X6), responsiveness (X8) does not significantly influence Loyalty. So that the obtained sub-structure equation 2:

$$
\mathrm{Y}=0,086 \mathrm{X}_{1} \mathrm{Y}+0,099 \mathrm{X}_{7} \mathrm{Y}+0,501 \mathrm{ZY}+0,574 \mathrm{e}_{2}
$$


The Impact of Service Quality Dimension on Patient Satisfaction and Loyaty Using the Modified Servqual Scala at dr.Abdoer Rahem Situbondo Hospital

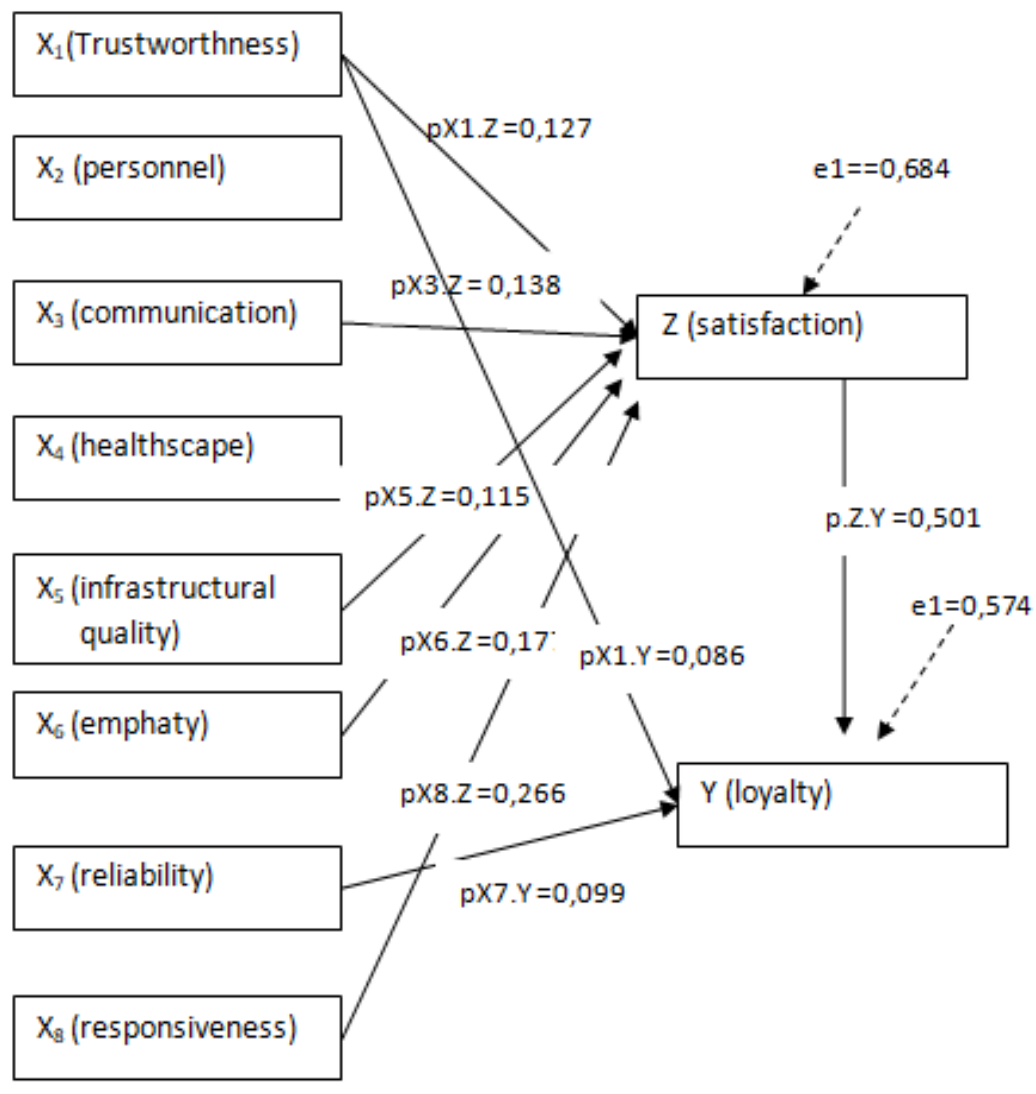

Figure 1. Path Coefficient Values Path Analysis Structures 1 and 2

Table 3.3. Summary of decomposition of the path coefficient, direct and indirect effects and the effect of total dimensions of Servqual (service quality) hospitalization; Trustworthness $\left(\mathrm{X}_{1}\right)$, Personnel $\left(\mathrm{X}_{2}\right)$, Communication $\left(\mathrm{X}_{3}\right)$, Healthscape $\left(\mathrm{X}_{4}\right)$, infrastructural quality $\left(\mathrm{X}_{5}\right)$, Emphaty $\left(\mathrm{X}_{6}\right)$, Reliability $\left(\mathrm{X}_{7}\right)$ and Responsiveness $\left(\mathrm{X}_{8}\right)$, satisfaction $(\mathrm{Z})$ to loyalty $(\mathrm{Y})$.

\section{Path coefficient}

\begin{tabular}{lllll} 
Influence of & \multicolumn{3}{c}{ Total } & Conclusion \\
\cline { 2 - 3 } & Variables & direct & Indirect trhough $Z$ & \\
\hline$X_{1}$ to $Z$ & 0.127 & - & 0.127 & Signifikan \\
$X_{2}$ to $Z$ & -0.011 & -0.011 & Not signifikan \\
$X_{3}$ о $Z$ & 0.138 & 0.138 & Signifikan \\
$X_{4}$ to $Z$ & 0.073 & 0.115 & 0.073 & Not signifikan \\
$X_{5}$ to $Z$ & 0.177 & - & 0.115 & Signifikan \\
$X_{6}$ to $Z$ & 0.087 & - & 0.177 & Signifikan \\
$X_{7}$ to $Z$ & 0.226 & - & 0.087 & Not signifikan \\
$X_{8}$ to $Z$ & & - & 0.226 & Signifikan
\end{tabular}




$\begin{array}{lllll}X_{1} \text { to } Y & 0.086 & (0,127 \times 0,501)=0.064 & 0.150 & \text { Signifikan } \\ X_{2} \text { to } Y & 0.028 & (-0,011 \times 0,501)=-0.006 & 0.022 & \text { Not signifikan } \\ X_{3} \text { о Y } & 0.079 & (0.138 \times 0,501)=0.069 & 0.148 & \text { Signifikan } \\ X_{4} \text { to Y } & 0.043 & (0.073 \times 0,501)=0.037 & 0.080 & \text { Not signifikan } \\ X_{5} \text { to } Y & -0.033 & (0.115 \times 0,501)=0.058 & 0.025 & \text { Not signifikan } \\ X_{6} \text { to } Y & 0.080 & (0.177 \times 0,501)=0.089 & 0.169 & \text { Signifikan } \\ X_{7} \text { to } Y & 0.099 & (0.087 \times 0,501)=0.044 & 0.143 & \text { Signifikan } \\ X_{8} \text { to } Y & 0.088 & (0.226 \times 0,501)=0.113 & 0.201 & \text { Signifikan } \\ \text { Z to } Y & 0.501 & - & 0,501 & \text { Signifikan }\end{array}$

(Research Results)

B. Discussion of Research Result

In this discussion an in-depth analysis related to the influence of the quality of inpatient health services on satisfaction and loyalty, as follows:

1. Effect of Service Quality on Satisfaction

In the research hypothesis $(\mathrm{Hl})$ it was stated that all dimensions of service quality in the form of trustworthness (X1), Personnel (X2), Communication (X3), Healthscape (X4), infrastructural quality (X5), Emphaty (X6), Reliability (X7) and Responsiveness (X8) have a significant effect on inpatient satisfaction. This is in line with the results of the analysis of researchers that the quality of inpatient health services through the dimensions trustworthness, Communication, infrastructural quality, Emphaty and Responsiveness significantly influence patient satisfaction and the most dominant influence is responsiveness. This means that three indicator dimension (the personnel, healthscape and reliability) has no effect on patient satisfaction. The results of this study are slightly different from the study by Meesala (2016) who found only the dimensions of reliability and responsiveness) affect patient satisfaction, and Andaleeb (2001) who found that tangible, responsiveness and assurance affect patient satisfaction and the tangible dimension has the greatest impact on satisfaction patients, as well as Sadeh (2017) that the tangible dimension / physical evidence has the strongest influence on patient satisfaction.

The dimension of responsiveness that has the greatest impact on patient satisfaction may be caused by patients with sick and weak conditions who are eager to get well or be served immediately so that responsiveness is the most important thing, because it involves the speed of healing the disease and even the safety of his life. The faster the response of specialists in visiting the more satisfied patients, where the maximum limit is at 14.00 Western Indonesian Time. Visitation means the doctor checks the patient's condition accompanied by a nurse and provides clinical instructions such as laboratory and radiological tests to confirm the patient's diagnosis and prescribe medication. At this stage the doctor will immediately explain the 
patient's related illness. Therefore Responsiveness / responsiveness is the most dominant dimension of service quality affecting patient satisfaction.

\section{Effect of Service Quality Mediated by Satisfaction on Loyalty}

The hypothesis which says that all dimensions of service quality has a significant effect on loyalty in the inpatient services of RSUD dr. Abdoer Rahem Situbondo has not been proven true. But only two (2) dimensions of service quality directly have a positive and significant effect on patient loyalty, namely trustworth and reliability. Indirect testing obtained that dimensions of trustworthness, Communication, Emphaty, Reliability and Responsiveness affect loyalty through patient satisfaction and the other hand the personnel, healthscape, infrastructural quality dimensions does not affect loyalty through patient satisfaction.

This agrees with Zhang et al (2018) the dimensions of responsiveness and reliability (soft aspeck) quality mediated by empathy have an effect on loyalty, Bloemer and Wezels (1999) the empathy dimension has a positive effect on loyalty through gethok tular communication / from mouth mouths and repurchases. Meesala, Paul J. (2016), the dimensions of reliability, responsiveness mediated by satisfaction affect patient loyalty. But the researchers' findings differ from the results of Sadeh's (2017) study where the Tangible quality dimension has the most significant effect on loyalty, especially on positive indicators of word of mouth, and the desire to reuse.

\section{Effect of Patient Satisfaction on Loyalty}

Hypothesis testing has shown that patient satisfaction in the inpatient service unit of RSUD dr. Abdoer Rahem Situbondo has a positive effect of $50.1 \%$ on loyalty. This means that every 1 time increase in inpatient satisfaction will lead to loyalty of 0.50 times. or the level of satisfaction influence on loyalty according to Sarwono (1998) is a strong influence. The results of this study contradict the opinions and research results of Kessler and Mylod (2009) that there is a significant relationship between satisfaction and loyalty, but the effect of satisfaction on loyalty is relatively small in accordance with the results of the study. While Puspitasari and Idris (2016) who found that satisfaction affected the level of patient loyalty, Hidajahningtyas et al. (2013); patient satisfaction has a significant effect on patient loyalty, Amin and Nazarudin (2013) patient satisfaction has a significant influence on repurchase behavior.

The positive influence of patient satisfaction on loyalty needs to be the concern of the hospital side to continue to improve the quality of inpatient services by meeting patient expectations so as to cause satisfaction. Patients with satisfying experiences will return to the hospital when they are sick, this is what according to Oliver (1999) is called loyal patients, namely customers who have a strong commitment to buy again or subscribe to certain products or services in the future despite the influence situation.

\section{CONCLUSION}

Based on all the explanations explained in the analysis and discussion section, it can be concluded that the first; the quality of health services concerning the dimensions of 
trustworthness, communication, infrastructural quality, emphaty and responsiveness have a positive and significant effect on patient satisfaction in the inpatient installation of RSUD dr. Abdoer Rahem Situbondo with the dimension of responsiveness that has the greatest impact on satisfaction, but the dimension of personnel, healthscape and reliability does not have a significant effect, second; the quality of health services regarding the dimensions of trustworthness, Communication, Emphaty, Reliability and Responsiveness through patient satisfaction have a positive and significant effect on patient loyalty in the inpatient installation of RSUD dr. Abdoer Rahem Situbondo but the personnel, healthscape, infrastructural quality does not have a significant effect. Third, patient satisfaction at the inpatient facility has a positive and significant effect on patient loyalty.

\section{REFERENCES}

Aagja dan Garg, 2010. Measuring perceived service quality for public hospitals (PubHosQual) in the Indian context. International Journal of Pharmaceutical and Healthcare Marketing, Vol. 4 Iss 1 pp. 60 - 83. Emerald Group Publishing Limited.

Amin M, Nasharudin Siti ,Z. 2012. Hospital service quality and its effect on patient satisfaction and behavioural intention. Clinical government an International Journal. Vol 18 No.3 Halaman 235-248. Emerald Group Publishing Limited.

Andaleb. 2001. Service quality perceptions and patient satisfaction: a study of hospitals in a developing country, Social Science dan Medicine 52 (2001) 1359-1370, Elsevier Science Ltd.

Babakus dan Mangold .1995. Adapting the SERVQUAL Scale to Hospital Services: An Empirical Investigation.Health Services Research vol 26 No.6 pp767-785.

Bei, Chiao .2006. the determinants of customer loyalty: an analysis of intangible factors in three service industries (gas station service, banking,Auto service dan maintenance).IJCM Vol.16 (3dan4), 2006 162, Emerald Group Publishing Limited.

Bloemer danWetzels, 1999,"Linking perceived service quality and service loyalty: a multi-dimensional perspective", European Journal of Marketing, Vol. 33 Iss 11/12 pp. 1082 - 1106, Emerald Group Publishing Limited.

Chahal, Bala. 2012. Significant components of service brand equity in healthcare sector. International journal of health care Quality assurance. Vol 25. No.4 pp 343-362Emerald Group Publishing Limited.

Choi dan Choi .2014. the effect of perceived service recovery justice on customer affection, loyality and word of mouth. European Journal of Marketing vol 48.no.1/2/. Emerald Group Publishing Limited.

Choi et., al. 2005, The service quality dimensions and patient satisfaction relationships in South Korea: comparisons across gender, age and types of service, Journal of Services Marketing 19/3 (2005) 140-149 q Emerald Group Publishing Limited.

Cronin dan Taylor. 1992, Measuring service quality - a rexamination and extension, Journal of marketing, 56. 3, Abi/inform global page. 55. 
Donabedian. 1992. Quality assurance in health care: consumers' role, Quality in Health Care 1992;1:247-25l.. BMJ group.

Duggirala et al,2008, Patient-perceived dimensions of total quality service in healthcare, Benchmarking: An International Journal Vol. 15 No. 5, 2008 pp. 560-583, Emerald Group Publishing Limited.

Fahrozy. 2017. Hubungan kualitas pelayanan rumah sakit dengan kepuasan pasien pengguna BPJS Kesehatan di RS Abdoer Wahab Sjahranie Samarinda. Psikoborneo vol.5, no.l hal 118-124.Samarinda.

Fatima et. Al.2018, Hospital Healthcare Service Quality, Patient Satisfaction and Loyalty: An Investigation in context of Private Healthcare Systems of Pakistan, International jurnal of quality and reliability Management, Emerald Group Publishing Limited.

Gerson R.F.2002. Mengukur kepuasan pelanggan, panduan menciptakan pelayanan bermutu, Jakarta, Penerbit PPM.

Giese dan Cote. 2002. Defining Consumer Satisfaction, Academy of Marketing Science Review, Volume 2000 No. 1.

Griffin, Jill. 2005. Customer Loyality: Menumbuhkan dan Mempertahankan Kesetiaan Pelanggan. Jakarta: Erlangga.

Gronroos.1984.A Service Quality Model and its Marketing Implications, European Journal of Marketing, Vol. 18 Issue: 4, pp.36-44. Emerald Group Publishing Limited.

Hardiansyah, 2018. Kualitas pelayanan publik. Yogyakarta. Penerbit Gavamedia.

Hasan, 2013. Marketing dan Kausus-kasus Pilihan Yogyakarta: Center for Academic Publishing Service, 2013), h. 126.

Hawkins et., al.2000. Customer Behaviour. Copy right by Mc Grow Hill Companies Inc.

Hidajahningtyas dkk. 2013. Pengaruh citra, kualitas layanan dan kepuasan terhadap loyalitas pasien di Poliklinik eksekutif rumah sakit daerah dr. Soebandi Kabupaten Jember. JEAM vol.xii Nol. Universitas Jember.

Kessler dan mylod. 2011. Does patient satisfaction affect patient loyalty? International Journal of health care Quality assurance, Vol.24 No.4.pp-266-273. Emerald Group Publishing Limited.

Kotler, Philips. 1994. Marketing management; analysis, Planning, implementation and control, Eighth editions, New York:Prentice hall.

Kronenfeld, 2007. Access, Quality and Satisfaction: Three Critical Concepts in Health Services and Health Care Delivery, Research in the Sociology of Health Care, Volume 24, 3-14. Emerald Group Publishing Limited.

Lovelock, Lauren.1999. Principles of service marketing and management, Upper Saddle River, N.J Prentice Hall.

Maftukhah dan Asmoro, 2017. Pengaruh kualitas layanan, citra merk, inovasi terhadap kepuasan pasien rawat inap pada RS Keluarga sehat di Kabupaten Pati, Manajemen Analisis Journal 6(1), Semarang, Universitas Negeri Semarang. 
Meesala dan Paul, 2016. Service quality, customer satisfaction and loyaly in hospital: thingking for the future. Journal of Retaining and Consumer service. Elsevier.

Oliver. R.L. 1999, Whence consumer loyalty?, Journal of Marketing, Vol. 63 No. 1, pp. 33-44.

Oliver. RL , 1980, A Cognitive Model of the Antecedents and Consequences of Satisfaction Decisions, Journal of Marketing Research Vol. XVII (November 1980), 460-9.

Padma et., al. 2009. A conceptual framework of service quality in healthcare, Perspectives of Indian patients and their attendants. Benchmarking: An International Journal Vol. 16 No. 2, 2009 pp. 157-191. Emerald Group Publishing Limited.

Padma et., al. 2010.Service quality and its impact on customer satisfaction in Indian hospitals, Perspectives of patients and their attendants.Benchmarking: An International Journal Vol. 17 No. 6, 2010 pp. 807-841 q Emerald Group Publishing Limited.

Pai, Y.P dan Chary .2016. Measuring patient-perceived hospital service quality: a conceptual framework. International Journal of Health Care Quality Assurance, Vol. 29 no. 3, Emerald Group Publishing Limited.

Parasuraman, 2010. Service productivity, quality, and innovation, implications for service -design practice and research. International journal of quality and service sciences. Vol 2 no.3 -pp 277-286. Emerald group publishing Limited.

Parasuraman, Berry, Zeithaml. 1988.SERVQUAL: A multiple-Item Scale for measuring consumer perceptions of service quality. Journal of retailing. Vol. 64, No 1, pp. 12 40 .

Pertiwi. 2016. Analisis perbedaan kualitas pelayanan pada pasien BPJS dan pasien umum terhadap kepuasan pasien di rawat jalan RSUD Kota Surakarta.DayaSaing Jurnal ekonomi dan manajemen sumber daya vol 18 no.2. Surakarta. Universitas Muhamadiyah.

Rangkuti, 2003. Measuring customer satisfaction, teknik mengukur dan strategi meningkatkan kepuasan pelanggan plus analisis kasus PLN-JP, Jakarta, Gramedia Pustaka Utama.

Riduwan, Kuncoro. 2007. Cara menggunakan dan memaknai analisis jalur (Path Analysis), Alfabeta, Bandung.

Sangadji, Sopiah . 2010. Metodologi Penelitian, pendekatan praktis dalam penelitian. Yogyakarta, Penerbit Andi.

Sohail M.S, 2003. Service quality in hospital: More favourable than you might think, Managing Service Quality: An International Journal, Vol.13 No.3 hal 197-206, Emerald Group Publishing Limited.

Sugiyono, 2013, Statistika untuk penelitian, Bandung, Penerbit Alfabeta.

Sugiyono. 2018. Metode Penelitian Kuantitatif. Bandung. Penerbit Alfabeta.

Swain, Kar. 2018. Hospital service quality as antecedent of patient satisfaction -a conceptual framework. International Journal of Pharmaceutical and Healthcare Marketing. Emerald Group Publishing Limited. 
Tjiptono dan Chandra 2018. Service, quality dan satisfaction. Edisi 4. Yogyakarta. Penerbit Andi.

Trail et., al. 2016. An examination of Oliver's product loyalty framework", International Journal of Sports Marketing and Sponsorship, Vol. 17 Iss 2 pp. 94 - 109. Emerald Group Publishing Limited.

Trisnawati dan Fitriani. 2015. Pengaruh kualitas pelayanan terhadap loyalitas melalui kepuasan pasien pengguna BPJS di Rawat Inap RSUD dr. Moewardi.Jurnal ekonomi Manajemen sumber daya vol.17 no.l. Yogyakarta. Unmuh Yogyakarta.

Wang et., al.2014. Trust transfer and the effect of service quality on trust in healthcare industry.Managing Service quality vol24. No.4. pp 399-416. Emerald group publishing Limited.

Yunida .2016. Pengaruh citra rumah sakit dan kualitas pelayanan terhadap Loyalaitas pelanggan melalui Kepuasan Pelanggan (studi pada RS Amal Sehat Wonogiri). Tidak diterbitkan. Skripsi. Yogyakarta, Universitas Negeri Yogyakarta.

Zhang et., al. 2018. Hospital service quality and patient loyalty: the mediation effect of empathy, Journal of Business dan Industrial Marketing, Emerald Group Publishing Limited. 